\title{
Concrete Mix Design with Portland Pozzolana Cements
}

\author{
T. Yathish
}

The Indian standard IS:456-2000 recommends the use of Portland pozzolana cement formerly known as blended cement as well as mineral admixtures for concrete mixes provided that there are satisfactory data on their suitability, such as performance test on concrete containing them. In the present paper concrete mix design with blended cement is presented based on relevant latest I.S. codes.

\section{Introduction}

Concrete is a widely used structural material consisting essentially of a binder and a mineral filler. It has the unique distinction of being the only construction material actually manufactured on the site, or in a RMC plant.

Concrete has become an indispensable construction material. In the present scenario concrete has crossed the stage of four component system i.e. cement, water, coarse aggregate and fine aggregate. It can be combination of more number of ingredients such as fly ash, ground granulated blast furnace slag, silica fume, rice husk ash and admixtures etc. are generally used in concrete production in practice which depends upon the requirement and the availability of the expertise.

The fundamental requirement of a concrete mix is that it should be satisfactory both in the fresh as well as in the hardened state, possessing certain minimum desirable properties like workability, strength and durability. Besides these requirements it is essential that the concrete mix is prepared as economically as possible by using the least possible amount of cement content per unit volume of concrete, with due regard to the strength and durability requirements. Since concrete is produced by mixing several discrete material, the number of variables governing the choice of mix design are necessarily large. However continuous research work in this field by various investigators, has helped to identify the major parameters controlling the proportions of ingredients in the mix.

\section{Principle of Mix Design}

The basic principle which is generally used for mix design for proportioning mixes is Abram's law for strength development. According to this law, for any given conditions of test the strength of workable concrete mix is dependant only on the water-cement ratio. Lesser the water-cement ratio in a workable mix greater will be its strength. From practical considerations compressive strength is taken as an index of acceptability. Mix proportioning is normally carried out for a specific characteristic compressive strength requirements ensuring that the mix so proportioned should satisfy the workability requirements without segregation and bleeding of concrete.

\section{Data For Mix Design}

The following data are required for mix design:

- Grade designation

- Type of cement

- Maximum nominal size of aggregate

- Minimum cement content

- Maximum water-cement ratio

- Workability

- Maximum cement content

- Any admixture used

- Exposure conditions (as per IS: 456)

- Method of transportation and placing of concrete

\section{Mix Design Procedure}

i. Target mean strength

$F_{t}=f_{c k}+1.65 \times S$ 
Where,

$\mathrm{F}_{\mathrm{t}}=$ Target mean strength at 28 days in $\mathrm{N} / \mathrm{mm}^{2}$

$\mathrm{f}_{\mathrm{ck}}=$ Characteristic compressive strength at 28 days in $\mathrm{N} / \mathrm{mm}^{2}$

$\mathrm{S}=$ Standard deviation

ii. Selection of water-cement ratio

\begin{tabular}{|l|l|l|}
\hline \multicolumn{2}{|c|}{ Table 3: Environmental Exposure Conditions (Clauses 8.2.1 and 35.3.2 } \\
\hline $\begin{array}{l}\text { SI. } \\
\text { No. }\end{array}$ & Environment & Exposure Conditions \\
\hline i) & Mild & Concrete surfaces protected against weather or aggressive conditions, except those situated in coastal area. \\
\hline ii) & Moderate & $\begin{array}{l}\text { Concrete surfaces sheltered from severe rain or freezing whilst wet Concrete exposed to condensation and } \\
\text { rain Concrete continuously under water Concrete in contact or buried under non-aggressive soil/ground } \\
\text { water Concrete surfaces sheltered from saturated salt air in coastal area }\end{array}$ \\
\hline iii) & Severe & $\begin{array}{l}\text { Concrete surfaces, exposed to severe rain, alternate wetting and drying or occasional freezing whilst wet or } \\
\text { severe } \\
\text { Concrete completely immersed in sea water Concrete exposed to coastal environment }\end{array}$ \\
\hline iv) & Very severe & $\begin{array}{l}\text { Concrete surfaces exposed to sea water spray, corrosive fumes or severe freezing conditions whilst wet } \\
\text { Concrete in contact with or buried under aggressive sub-soil/ground water }\end{array}$ \\
\hline v) & Extreme & \begin{tabular}{l} 
Surface of members in tidal zone Members in direct contact with liquid/solid aggressive chemicals \\
\hline
\end{tabular} \\
\hline
\end{tabular}

This ratio should be selected based upon the relationship between target mean compressive strength of concrete and Compressive strength of cement. IS: 10262-1982 fig. 2 gives the values of water-cement ratio for various cements. The water-cement ratio can also be taken from table (5) of IS:456-2000 for particular environmental exposure conditions as starting point. The supplementary cementitious material that is mineral admixtures shall also be considered in water-cement ratio calculations.

The above selected water-cement ratio should be checked against limiting water-cement ratio for the requirement s of durability and the lower of the two will be adopted.

Table 5: Minimum Cement Content, Maximum Water-Cement Ratio and Minimum Grade of Concrete for Different Exposures with Normal Weight Aggregates of 20 mm Nominal Maximum Size

Clauses 6.1.2, 8.2.4.1 and 9.1.2)

\begin{tabular}{|c|c|c|c|c|c|c|c|}
\hline \multirow[b]{2}{*}{$\begin{array}{l}\text { SI. } \\
\text { No. }\end{array}$} & \multirow[b]{2}{*}{ Exposure } & \multicolumn{3}{|c|}{ Plain Concrete } & \multicolumn{3}{|c|}{ Reinforced Concrete } \\
\hline & & $\begin{array}{l}\text { Minimum Cement } \\
\text { Content } \mathrm{kg} / \mathrm{m}^{3}\end{array}$ & $\begin{array}{l}\text { Maximum Free } \\
\text { Water-cement } \\
\text { Ratio }\end{array}$ & $\begin{array}{l}\text { Minimum Grade } \\
\text { of Conrete }\end{array}$ & $\begin{array}{l}\text { Minimum Cement } \\
\text { Content } \mathrm{kg} / \mathrm{m}^{3}\end{array}$ & $\begin{array}{l}\text { Maximum Free } \\
\text { Water-cement } \\
\text { Ratio }\end{array}$ & $\begin{array}{l}\text { Minimum Grade } \\
\text { of Conrete }\end{array}$ \\
\hline (1) & (2) & (3) & (4) & (5) & (6) & (7) & (8) \\
\hline i) & Mild & 220 & 0.60 & - & 300 & 0.55 & M 20 \\
\hline ii) & Moderate & 240 & 0.60 & M 15 & 300 & 0.50 & M 25 \\
\hline iii) & Severe & 250 & 0.50 & M 20 & 320 & 0.45 & M 30 \\
\hline iv) & Very severe & 260 & 0.45 & M 20 & 340 & 0.45 & M 35 \\
\hline v) & Extreme & 280 & 0.40 & M 25 & 360 & 0.40 & M 40 \\
\hline \multicolumn{8}{|c|}{$\begin{array}{l}\text { Notes } \\
\text { 1. Cement content prescribed in this table is irrespective of the grades of cement and it is inclusive of additions mentioned in 5.2. The } \\
\text { additions such as fly ash or ground granulated blast furnace slag may be taken into account in the concrete composition with respect to the } \\
\text { cement content and water-cement ratio if the suitability is established and as long as the maximum amounts taken into account do not } \\
\text { exceed the limit of pozzolona and slag specified in IS } 1489 \text { (Part 1) and IS } 455 \text { respectively. }\end{array}$} \\
\hline
\end{tabular}

Selection of water content

The water content i.e. the quantity of maximum mixing water per unit volume of concrete may be determined from the following table: 
Concrete Mix Design with Portland Pozzolana Cements

\begin{tabular}{|l|l|l|}
\hline \multicolumn{1}{|c|}{ S.No. } & \multicolumn{1}{c|}{ Nominal maximum size of agg. } & \multicolumn{1}{c|}{ Maximum water content } \\
\hline 1. & $10 \mathrm{~mm}$ & $208 \mathrm{~kg}$ \\
\hline 2. & $20 \mathrm{~mm}$ & $186 \mathrm{~kg}$ \\
\hline 3. & $40 \mathrm{~mm} \quad$ The above table is for angular coarse aggregates and for 25 to $50 \mathrm{~mm}$ slump range. \\
\hline \multicolumn{2}{|r}{} & \\
\hline
\end{tabular}

iii.

Note:

a. The water estimates can be reduced by approximately $10 \mathrm{~kg}$ for sub-angular aggregates, $20 \mathrm{~kg}$ for gravel with some crushed particles \& $25 \mathrm{~kg}$ for rounded gravel to produce same workability.

b. For desired workability (other than 25 to $50 \mathrm{~mm}$ slump range) the required water content may be increased by about 3 percent for every additional $25 \mathrm{~mm}$ slump or alternatively by use of chemical admixtures.

c. Water reducing admixtures usually decrease water content by 5 to 10 percent and 20 percent and above respectively at appropriate dosages.

iv. Cementitious material content

This may be calculated from the free water-cement ratio and the quantity of water per unit volume of concrete. The cementitious material content so calculated shall be checked for minimum content for the durability requirements and the greater of the two values adopted. The maximum cement content shall be as per IS: 456-2000.

v. Proportioning of coarse aggregate content

For a water-cement ratio of 0.5 approximate values of aggregate volume is given in the following table.

\begin{tabular}{|c|c|c|c|c|c|}
\hline \multicolumn{6}{|c|}{ Table: Volume of coarse aggregate per unit volume of total Aggregate for different Zones of Fine Aggregate } \\
\hline \multirow[t]{2}{*}{ S, No. } & \multirow{2}{*}{$\begin{array}{l}\text { Nominal Maximum Size of Aggregate } \\
\mathrm{mm}\end{array}$} & \multicolumn{4}{|c|}{$\begin{array}{l}\text { Volume of Coarse Aggregate* per unit Volume of Total Aggregate for Different } \\
\text { Zones of Fine Aggregate }\end{array}$} \\
\hline & & Zone IV & Zone III & Zone II & Zone I \\
\hline 1 & 2 & 3 & 4 & 5 & 6 \\
\hline i) & 10 & 0.50 & 0.48 & 0.46 & 0.44 \\
\hline ii) & 20 & 0.66 & 0.64 & 0.62 & 0.6 \\
\hline iii) & 40 & 0.75 & 0.73 & 0.71 & 0.69 \\
\hline
\end{tabular}

Note:

a. Adjust volume of coarse aggregate for decrease in w/c ratio by 0.05 the increase in coarse aggregate by $1 \%$.

b. For more workable concrete such as pumped concrete etc the above estimated coarse aggregate content may be reduced by up to $10 \%$.

vi. Determination of Fine Aggregate Content:

This is obtained by finding out the absolute volume of cementitious material; water and the chemical admixture by dividing their masses to their specific gravity, multiplying by $1 / 1000$ subtract the results of this summation from unit volume.

The above obtained values are distributed into coarse and fine aggregate fractions by volume in accordance with coarse aggregate fractions.

The coarse and fine aggregates contents are then determined by multiplying with their respective specific gravities and multiplying by 1000 .

\section{vii. Trial Mixes}

The trial mixes shall be made and cubes be tested, if any discrepancies may be observed during concrete making it should be taken into considerations and more trial mixes be prepared and finally the mix which provides sufficient information, including the relationship between compressive strength, water cement ratio and slump, from which the mix proportions for field trials may be arrived at. The concrete for field trials shall be produced by methods of actual concrete production. 


\section{viii. Example}

$\begin{array}{ll}\text { Grade of Designation } & \text { M-25 } \\ \text { Type of Cement } & \text { PPC confirming to Is1489 - Part I } \\ \text { Maximum Nominal Size of Aggregate } & 20 \mathrm{~mm} \\ \text { Minimum Cement Content } & 300 \mathrm{~kg} \\ \text { Maximum water cement ratio } & 0.5 \\ \text { Workability } & 60 \mathrm{~mm} \text { slump } \\ \text { Type of Aggregate } & \text { Crushed Angular aggregate } \\ \text { Maximum Cement Content } & 450 \mathrm{~kg} / \mathrm{m}^{3} \\ \text { Chemical Admixtures } & \text { Fosroc (as supplied) }\end{array}$

\begin{tabular}{|l|l|l|l|l|l|l|l|}
\hline \multicolumn{7}{|c|}{ Sieve Analysis of Coarse Aggregate } \\
\hline IS sieve No & Analysis of Coarse Aggregate Fraction, \% passing & Percentage of Different Fractions & Remarks \\
\hline & I & II & & I & II & Combined & \\
\hline & & 100 & $30 \%$ & $70 \%$ & $100 \%$ & Conforming to Table: 2 of IS383 \\
\hline $10 \mathrm{~mm}$ & 0.8 & 47 & 24.3 & 70 & 94.3 & \\
\hline $4.75 \mathrm{~mm}$ & 0 & 4.4 & .24 & 32.9 & 33.14 & & \\
\hline $2.36 \mathrm{~mm}$ & - & - & 0 & 3.08 & 3.08 & & \\
\hline
\end{tabular}

\begin{tabular}{|l|l|l|}
\hline IS sieve No & Percentage passing & Remarks \\
\hline $4.75 \mathrm{~mm}$ & 100 & \multirow{2}{*}{ Conforming to Zone IV Table 4 of IS383 } \\
\hline $2.36 \mathrm{~mm}$ & 98.5 & \\
\hline $1.18 \mathrm{~mm}$ & 96 & \\
\hline $600 \mu \mathrm{m}$ & 85 & \\
\hline $300 \mu \mathrm{m}$ & 3 & \\
\hline $150 \mu \mathrm{m}$ & 0 & \\
\hline
\end{tabular}

Target Mean Strength $F_{t}=f_{c k}+1.65 S$

$=25+1.65 * 4.0$

$=31.6 \mathrm{~N} / \mathrm{mm}^{2}$

The mix proportions obtained for above materials are:

Water : Cement : Sand : Aggregate $=184.5$ lits: $410 \mathrm{~kg}: 606 \mathrm{~kg}: 1176 \mathrm{~kg}$

$\mathrm{w} / \mathrm{c}$ ratio $=0.45,1: 1.478: 2.868$

Admixture dose $=0.25 \%$ of weight of cement in terms of volume of admixture

Cube strength after 7 days $=24.0 \mathrm{~N} / \mathrm{mm}^{2}, 20.88 \mathrm{~N} / \mathrm{mm}^{2}, 22.22 \mathrm{~N} / \mathrm{mm}^{2}$

Average Value $=22.36 \mathrm{~N} / \mathrm{mm}^{2}$

Cube strength after 28 days $=31.11 \mathrm{~N} / \mathrm{mm}^{2}, 34.66 \mathrm{~N} / \mathrm{mm}^{2}, 31.11 \mathrm{~N} / \mathrm{mm}^{2}$

Average Value $=32.29 \mathrm{~N} / \mathrm{mm}^{2}$

\section{Conclusions}

The concrete mix produced with blended cements (PPC Cement) possesses nearly same quality as of OPC except with adjustments in water cement ratio as such the heat of hydration of PPC is lower than OPC the 
cement content obtained is slightly higher for blended cements. Hence, it is concluded that with proper quality control and supervision at site, the effectiveness of concrete produced with blended cements will be increased. It will also satisfy the requirements of workability, strength and durability.

\section{References}

[1]. IS:456-2000 (fourth revision)code of practice for plain and reinforced concrete structures, BIS New Delhi

[2]. IS:10262-1982, Recommended guideline for conc. mix design, BIS, Feb 1983, BIS New Delhi.

[3]. IS:10262-2009, Concrete mix proportioning - Guide lines July, 2009, BIS New Delhi.

[4]. IS:383 - 1970, Specification for coarse and Fine aggregates from natural sources for concrete BIS New Delhi.

[5]. Shetty, M. S., Concrete Technology Theory and Practice, 2005, S Chand \& Co. New Delhi.

[6]. Roy Sabyasachi, Pumped concrete with admixtures, Civil Engineering \& Construction Review, 2004 pp 51-54

[7]. N. Krishnaraju, Design of Concrete Mixes, CBS publishers, Delhi, 1993 